\title{
Entrepreneurial Market Orientation and Marketing Performance: An Evidence from Malang Soybean Cracker Industry
}

\author{
Ananda Sabil Hussein ${ }^{1}$ \\ Fakultas Ekonomi dan Bisnis, Universitas Brawijaya, Malang, 65143, sabil@ub.ac.id
}

Diterima: 08/08/2018

Direview: 18/10/2019

Diterbitkan: 28/11/2019

Hak Cipta @ 2019 oleh Penulis (dkk) dan Jurnal Sosial Humaniora (JSH)

*This work is licensed under the Creative

Commons Attribution International License (CC

BY 4.0).

http://creativecommons.org/licenses/by/4.0/

Open Access

\begin{abstract}
Subject Area: Entrepreneur (Enterpreneur)
Abstract This study aims to test the effect of entrepreneurial market orientation (EMO) as the development of entrepreneurial orientation concept. Particularly, this study tested the dimensions of EMO, namely innovation, customer orientation, market orientation and entrepreneurial orientation on marketing performance. To answer the proposed research objectives, this study applied multiple regression analysis. Self-administered questionnaires were distributed to one hundred respondents and only 67 questionnaires were collected. The results of multiple regression showed that innovation has a positive significant effect on marketing performance. Similar to innovation, this study indicated that customer orientation has a positive significant effect on marketing performance. As proposed in the hypothesis, this study found that market orientation positively affects marketing orientation. Entrepreneurial orientation as the dimension of EMO shows a significant effect on marketing performance. After the completion of this study, both theoretical and practical contribution are provided.
\end{abstract}

Keywords: innovation; customer orientation; market orientation; entrepreneurial orientation

\section{Introduction}

Several studies have explained that Small and Medium Enterprises (SMEs) have an important role in contributing to national income. It cannot be denied that the greater the contribution of SMEs to the economy is, the stronger the economy of a country will be. The potential of economic and social superiority of SMEs marked by their capacity in creating job opportunities at the low level of capital costs, improving in forward and backward linkage between various sectors, creating opportunities for the development and adaptation of appropriate technologies as a pool of skills and pseudo worker skills, fill in an inefficient market niche for large companies, and as supporters of large-scale companies.

While giving some contributions to the national income, SMEs still have many problems. Based on world bank studies, there are four problems that are faced by the SMEs. The first problem is about the limited financial access owned by the SMEs; the second is the small business opportunities; the third is the limited capacity of human resources; and the last is government regulation and bureaucracy. To sustain its business as well as to tackle these four problems, SMEs must have high marketing performance.

Many factors have been identified as the predictor of marketing performance. The idea of entrepreneurial orientation has been identified as the predictor of market performance (Hormiga, de Saá-Pérez, Díaz-Díaz, 
Ballesteros-Rodríguez, \& Aguiar-Diaz, 2017; Li, Huang, \& Tsai, 2009). These studies showed that the higher entrepreneurial orientation is, the higher the marketing performance will be. However, these previous studies did not consider the uncertainty situation in the market place (Parnell, Lester, Long, \& Köseoglu, 2012). Thus, to fill this gap, this study develops the notion of entrepreneurial market orientation (EMO). In general, this notion is about individual entrepreneurial behavior oriented to the market. Jones and Rowley (2011) suggested four dimensions that must be owned by an entrepreneur oriented to the market. These dimensions are innovation, customer orientation, market orientation, and entrepreneurial orientation.

This study aims to test the effect of entrepreneurial market orientation on marketing performance. Especially, this study will focus on the effects of four dimensions of EMO name innovation, customer orientation, market orientation and entrepreneurial orientation on marketing performance. Upon the completion of this study, both theoretical and practical contributions are provided. For theoretical contribution, this study shows the effects of innovation, customer orientation, market orientation and entrepreneurial orientation as dimensions of EMO on marketing performance. For practical standpoint, this study will provide a guideline for SMEs practitioners in increasing marketing performance based on EMO.

\section{Literature Review}

This study developed the notion of entrepreneurial market orientation as the derivation of entrepreneurial orientation. Four dimensions were proposed as the part of entrepreneurial market orientation (Jones \& Rowley, 2011). They are innovation, customer orientation, market orientation, and entrepreneurial orientation. The following section will discuss these four dimensions. Innovation is always interpreted differently by some experts. Suryani (2008) explained that innovation is not only limited to products. Innovations can be ideas, ways or objects that are perceived by someone as something new. Innovation is also used to refer to the changes that can be felt as something new by people who experience it. However, in the context of marketing and consumer behavior, innovation is often associated with new products or services. New products refer to products that really have never existed before in the market and new in the sense that there are things that are not the same as either a refinement or improvement of previous products encountered by consumers in the market._Previous studies showed that innovation plays an important role in affecting marketing performance. The study of Wang and Wang (2012) suggested that the SMEs having high innovation will have better marketing performance. In accordance with this study, Hussein (2018) explained that in Indonesian creative industry sector, innovation has a significant role in affecting business performance. Based on these studies, it is proposed:

H1: innovation has a significant effect on marketing performance

\section{Customer Orientation}

Customer is the key success of a business performance, profit rates, and market share. The success of performance is very dependent on the customers who come to repurchase products produced by the company, and it will happen if customer is satisfied with the product bought (Assauri, 2013).

The concept of marketing continues to develop, especially for the concept of strategic marketing that is based on classic marketing concept where the company only emphasizes on the desires and interests of customers. 
The concept of customer orientation is based on a customer-oriented philosophy that focuses on promises that are feasible and must be fulfilled by the company. Customer is considered as an individual and the determination is definitively based on market research on the target, and its implementation is directed based on the goals and objectives of the company.

In the marketing paradigm, customer orientation has been recognized as the determinant of marketing performance. Some studies found that the more business organization oriented to the customer, the better the marketing performance will be (Appiah - Adu \& Singh, 1998; Brady \& Cronin, 2001; Lin \& Germain, 2003). Hence, it is proposed:

H2: customer orientation has a significant effect on marketing performance.

\section{Market Orientation}

The application of market orientation will have a positive effect on the performance of the company. Market orientation is very effective to gain and maintain competitive advantage starting with planning and coordination with all parts in the organization to satisfy the needs of consumers. For that reason, market orientation must emphasize the analysis of the needs and wants of the target market more effectively than the competitors in an effort to achieve competitive advantage.

The focus of market orientation on competitiveness is based on customer needs analysis. Hence, each company is required to be able to answer the needs and wants by consumers through either the creation of new products or the development of existing products in order to create superior value for consumers in a sustainable manner and can be the main capital for the company to be able to win competition in the market.

Previous studies showed that market orientation has a significant role in affecting business performance. These studies indicated that the more market orientation is, the higher the performance will be. Thus, it is proposed:

H3: market orientation has a significant effect on marketing performance

\section{Entrepreneurial Orientation}

Entrepreneurial marketing behavior comes from entrepreneurial thinking. Entrepreneurial thinking and its characteristics are determined by the domain of entrepreneurial marketing. According to Miller and Cardinal (1994) and Covin and Slevin (1994), entrepreneurs must be seen as innovative, risk takers, proactive, and opportunity oriented. Entrepreneurial orientation has been indicated as the predictor of marketing performance. For example the study of Zehir, Can and Karaboga (2015) showed that entrepreneurial orientation has a positive significant effect of marketing performance. For that reason, it is proposed:

H4: entrepreneurial orientation has a positive significant effect on marketing performance

\section{Research Method}

\section{Research Design}


As the aim of this study was to examine the effects of EMO's dimensions on marketing performance, an explanatory study was conducted by this study. Self-administered questionnaires were used to collect the data. Before conducting the data collection, a pilot study involving 25 respondents was conducted and showed that the measures used were valid and reliable. For this study, the collected data was analyzed by using multiple regression. The proposed regression model was:

$\mathrm{MP}=\alpha+\beta \operatorname{Ino}+\beta C O+\beta M O+\beta E O+e$

Ino = Innovation

$\mathrm{CO}=$ customer orientation

$\mathrm{MO}=$ market orientation

$\mathrm{EO}=$ entrepreneurial orientation

\section{Sample}

The respondents of this study were the owner of soybean cracker business in the central of soybean cracker industry, Sanan, Malang. One hundred self-administered questionnaires were distributed, but only 67 questionnaires were returned which yielded $67 \%$ response rate. The following is demographic profile based on the sample: $59.7 \%$ is male; around $40 \%$ is aged between 41 and 50; more than $50 \%$ has opened the business more than 5 years and around $52 \%$ are high school graduates. Table 1 shows the complete demographic data.

Table 1. Demography of Respondents

\begin{tabular}{|l|l|l|}
\hline Variable & & Percentage \\
\hline Gender & Male & $59.7 \%$ \\
\hline & Female & $40.3 \%$ \\
\hline Age & $21-30$ & $13.4 \%$ \\
\hline & $31-40$ & $23.8 \%$ \\
\hline & $41-50$ & $37.3 \%$ \\
\hline & $>50$ & $25.4 \%$ \\
\hline Business Duration & $1-5$ years & $40.2 \%$ \\
\hline & $>5$ years & $59.8 \%$ \\
\hline Education & High school & $52.2 \%$ \\
\hline & Undergraduate & $29.8 \%$ \\
\hline & Postgraduate & $10.4 \%$ \\
\hline & Doctoral & - \\
\hline
\end{tabular}

Source: Primary data

\section{Measurements}

The measures used for this study were adapted from several studies. Innovation was adapted from Masluhah (2012), customer and market orientation were adapted from Jones and Rowley (2011), entrepreneurial orientation was adapted from Zulkarnain (2014) and marketing performance was adapted from Wibowo (2013). Five-point Likert scale anchored from (1) strongly disagree to (5) strongly agree was employed in this study. The 
collected data was analyzed by using multiple regression. Prior to data analysis, validity and reliability tests were conducted. The result indicated that the data were valid and reliable.

\section{Results and Discussion}

Based on the analysis of the data using Multiple regression, the regression equation formed was: MP = $0.618+0.126 \mathrm{Ino}+0.425 \mathrm{CO}+0.472 \mathrm{MO}+0.397 \mathrm{EO}+\mathrm{e}$

MP = Marketing Performance

Ino = Innovation

$\mathrm{CO}=$ Customer Orientation

$\mathrm{MO}=$ Market Orientation

$\mathrm{EO}=$ Entrepreneurial Orientation

Before testing the proposed hypotheses, the regression equation was confirmed to be a Best Linear Unbiased Estimate (BLUE). Some tests like normality test, multicollinearity test and heterocedastisity test were conducted to confirm that the equation BLUE. The results showed that the data was normally distributed and it was free from multicollinear and heterocedastisity problems. F-test was conducted to make sure that the model was robust and could be used to make a prediction. The result of F-test showed that the value of F-test was larger than 1.960. Hence, the regression model could be used for prediction. Table 2 shows the results of multiple regression analysis.

Four hypotheses were proposed in this study. The first hypothesis states that innovation as the dimensions of EMO has a significant effect on marketing performance. The hypothesis tests showed that innovation had a positive significant effect on marketing performance $(t=2.103 ; \beta=0.245)$. It means hypothesis 1 is supported. This finding means the more innovative the business organization is, the higher the marketing performance will be. The effect of innovation on marketing performance theoretically strengthens previous studies found the importance of innovation in enhancing marketing performance (Hussein, 2018; Wang \& Wang, 2012). Practically, this finding implies that SMEs of soybean cracker must be innovative to enhance the performance of their marketing.

Apart from innovation, this study suggested that customer orientation had a significant effect on marketing performance as proposed by Hypothesis 2. The finding of statistical test indicated that customer orientation had a positive significant effect on marketing performance $(t=2.188 ; \beta=0.233)$. It validated the study of Grissemann, Plank, and Brunner-Sperdin (2013) and Zhu and Nakata (2007) who suggested the importance of customer orientation on marketing performance. By supporting Hypothesis 2, it means the more SMEs oriented to the customers are, the better marketing performance will be. This result implies that SMEs must understand the needs and wants of customers to enhance their marketing performance.

As proposed by Hypothesis 3, market orientation has a positive significant effect on marketing performance $(t=2.454 ; \beta=0.307)$. It means the more market orientation is, the better marketing performance will be. Similar to market orientation, this study found that entrepreneurial orientation had a positive significant 
effect on marketing performance $(t=2.252 ; \beta=0.234)$. The significant effect of market orientation on marketing performance was similar to previous studies (Kajalo \& Lindblom, 2015; Morgan \& Vorhies, 2018) that found the effect of market orientation on performance. Practically, it implies that in enhancing marketing performance, business organization must be market oriented.

In accordance with the effect of market orientation on marketing performance, this study found the effect of entrepreneurial orientation on marketing performance $(\mathrm{t}=2.252 ; \beta=0.397)$. This finding means Hypothesis 4 is supported. It implies that the higher entrepreneurial orientation is, the higher marketing performance will be. Theoretically, this finding supported previous studies such as Engelen, Kube, Schmidt, and Flatten (2014), Kajalo and Lindblom (2015) and Li et al. (2009) who also found the effect of entrepreneurial orientation on marketing performance. Practically, it implies that to have a good marketing performance, business person should have high entrepreneurial orientation.

Table 2. Multiple Regression Analysis.

\begin{tabular}{|c|c|c|c|c|c|}
\hline & \multicolumn{2}{|c|}{$\begin{array}{c}\text { Unstandardized } \\
\text { Coefficients }\end{array}$} & $\begin{array}{c}\text { Standardized } \\
\text { Coefficients }\end{array}$ & \multirow{2}{*}{ Sig. } \\
\cline { 2 - 6 } & $\mathrm{B}$ & Std. Error & Beta & & \\
\hline (Constant) & 0.618 & 2.728 & & 0.226 & 0.822 \\
\hline Innovation (Ino) & 0.265 & 0.126 & 0.245 & 2.103 & 0.041 \\
\hline $\begin{array}{c}\text { Customer } \\
\text { Orientation (CO) }\end{array}$ & 0.425 & 0.194 & 0.233 & 2.188 & 0.034 \\
\hline $\begin{array}{c}\text { Market } \\
\text { Orientation (MO) }\end{array}$ & 0.472 & 0.192 & 0.307 & 2.454 & 0.018 \\
\hline $\begin{array}{c}\text { Entrepreneurial } \\
\text { Orientation (EO) }\end{array}$ & 0.397 & 0.176 & 0.234 & 2.252 & 0.029 \\
\hline F-test 26.421; $\mathrm{R}^{2}=0.701$ & & & & \\
\hline
\end{tabular}

Source : Primary data

\section{Conclusion}

Upon the completion of answering the proposed research objectives, it can be concluded that, the four dimensions of EMO namely innovation, customer orientation, market orientation, and entrepreneurial orientation play important roles in affecting marketing performance.

Theoretically, this study contributes to the marketing strategy knowledge by giving evidence that EMO is an important determinant of marketing performance. For that reason, in the practical manner, SMEs practitioners especially in the area of soybean cracker manufacture must be innovative, customer and market oriented and also have high entrepreneurial orientation.

While this study giving both theoretical and practical contributions, some limitations were identified. First and foremost, the limitation was about the generalizability of population. As this study was conducted only in Sanan central soybean cracker industry in which most of the business is considered SMEs, the findings of this study cannot be generalized into other sectors. Second limitation was about the questionnaires used in this study. As this study used self-administered questionnaire, there was a potential to be biased. However, 
some steps had been taken to reduce the bias such as by avoiding the negative sentence and keep the questionnaire anonym.

\section{Literature Review}

Appiah-Adu, K., \& Singh, S. (1998). Customer orientation and performance: a study of SMEs. Management Decision, 36(6), 385-394. https://doi.org/10.1108/00251749810223592

Assauri, S. (2013). Manajemen Pemasaran. Jakarta: PT. Raja Grafindo Persada.

Brady, M. K., \& Cronin, J. J. (2001). Customer Orientation: Effects on Customer Service Perceptions and Outcome Behaviors. Journal of Service Research, 3(3), 241-251. https://doi.org/10.1177/109467050133005

Covin, J. G., \& Slevin, D. P. (1994). Corporate Entrepeneurship in High and Low Technology Industries. Journal of Euromarketing, 3(3-4), 99-127. https://doi.org/10.1300/J037v03n03_06 deLaplante, K. (2008).

Philosophy of Ecology: Overview. In Encyclopedia of Ecology (pp. 2709-2715). https://doi.org/10.1016/B978-008045405-4.00247-0

Engelen, A., Kube, H., Schmidt, S., \& Flatten, T. C. (2014). Entrepreneurial orientation in turbulent environments: The moderating role of absorptive capacity. Research Policy, 43(8), 1353-1369. https://doi.org/https://doi.org/10.1016/j.respol.2014.03.002

Grissemann, U., Plank, A., \& Brunner-Sperdin, A. (2013). Enhancing business performance of hotels: The role of innovation and customer orientation. International Journal of Hospitality Management, 33, 347356. https://doi.org/https://doi.org/10.1016/j.ijhm.2012.10.005

Hormiga, E., de Saá-Pérez, P., Díaz-Díaz, N. L., Ballesteros-Rodríguez, J. L., \& Aguiar-Diaz, I. (2017). The influence of entrepreneurial orientation on the performance of academic research groups: the mediating role of knowledge sharing. The Journal of Technology Transfer, 42(1), 10-32. https://doi.org/10.1007/s10961-015-9463-2

Hussein, A. S. (2018). The Importance of Knowledge Management Orientation Behaviour and Innovation on Business Performance: A Lesson from Indonesia Creative Economy Sector. Asia- Pacific Management and Business Application, 7(2), 79-90.

Jones, R., \& Rowley, J. (2011). Entrepreneurial marketing in small businesses: A conceptual exploration. International Small Business Journal, 29(1), 25-36. https://doi.org/10.1177/0266242610369743

Kajalo, S., \& Lindblom, A. (2015). Market orientation, entrepreneurial orientation and business performance among small retailers. International Journal of Retail \& Distribution Management, 43(7), 580-596. https://doi.org/10.1108/IJRDM-04-2014-0044

Krijnen, T., \& Verboord, M. (2016). TV genres' moral value: The moral reflection of segmented TV audiences. The Social Science Journal, 53(4), 417-426. https://doi.org/10.1016/j.soscij.2016.04.004

Lee, T. M. (2017). Chapter 10 - Does Classical Chinese Philosophy Reveal Alternative Rationalities? In Rationality (pp. 195-211). https://doi.org/10.1016/B978-0-12-804600-5.00010-6

Li, Y.-H., Huang, J.-W., \& Tsai, M.-T. (2009). Entrepreneurial orientation and firm performance: The role of knowledge creation process. Industrial Marketing Management, 38(4), 440-449. https://doi.org/10.1016/J.INDMARMAN.2008.02.004

Lin, X., \& Germain, R. (2003). Organizational structure, context, customer orientation, and performance: lessons from Chinese state-owned enterprises. Strategic Management Journal, 24(11), 1131-1151. https://doi.org/10.1002/smj.348

Masluhah, I. (2012). Pengaruh strategi inovasi terhadap kinerja UMKM pengrajin sandal'. Brawijaya.

Mihailović, D. T., Balaž, I., \& Kapor, D. (2016). Chapter 5 - Time in philosophy and physics. In 
Developments in Environmental Modelling (Vol. 29, pp. 43-50). https://doi.org/10.1016/B978- 0-44463918-9.00005-3

Miller, C. C., \& Cardinal, L. B. (1994). Strategic Planning and Firm Performance: A Synthesis of More Than Two Decades of Research. Academy of Management Journal, 37(6), 1649-1665. https://doi.org/10.5465/256804

Morgan, N., \& Vorhies, D. W. (2018). The Business Performance Outcomes of Market Orientation Culture and Behaviors. In V. D. W. (Ed.), Innovation and Strategy (Vol. 15, pp. 255-282). Emerald Publishing Limited. https://doi.org/10.1108/S1548-643520180000015012

Parnell, J. A., Lester, D. L., Long, Z., \& Köseoglu, M. A. (2012). How environmental uncertainty affects the link between business strategy and performance in SMEs: Evidence from China, Turkey, and the USA. Management Decision, 50(4), 546-568. https://doi.org/10.1108/00251741211220129

Suryani, T. (2008). Perilaku Konsumen; Implikasi Pada Strategi Pemasaran. Yogyakarta: Graha Ilmu.

Wang, Z., \& Wang, N. (2012). Knowledge sharing, innovation and firm performance. Expert Systems with Applications, 39(10), 8899-8908. https://doi.org/https://doi.org/10.1016/j.eswa.2012.02.017

Wibowo. (2013). Manajemen Kinerja. Jakarta: Rajawali Pres.

Zehir, C., Can, E., \& Karaboga, T. (2015). Linking Entrepreneurial Orientation to Firm Performance: The Role of Differentiation Strategy and Innovation Performance. Procedia - Social and Behavioral Sciences, 210, 358-367.https://doi.org/https://doi.org/10.1016/j.sbspro.2015.11.381 Zhu, Z., \&

Nakata, C. (2007). Reexamining the Link between Customer Orientation and Business Performance: The Role of InformationSystems. Journal of Marketing Theory and Practice, 15(3), 187-203. https://doi.org/10.2753/MTP1069-6679150301

Zulkarnain. (2014). Entrepreneural Marketing: Teori dan Implementasi. Yogyakarta: Graha Ilmu. 